\title{
A new model of information systems for public awareness about wildfires
}

\author{
P.-Y. Badillo ${ }^{1} \&$ C. Sybord ${ }^{2}$ \\ ${ }^{1}$ IRSIC-Medi@SIC Laboratory, Aix-Marseillle Université, France \\ ${ }^{2}$ Université Lumière de Lyon, France
}

\begin{abstract}
In the framework of the FIRE PARADOX European project we have to define a public awareness strategy concerning a new management of wildfires. This strategy relies firstly on the identification of stakeholders and communication flows. To grasp the complexity of the topics we construct a first information system and then we propose to enrich this information system so that it could allow the analysis, the validation and the organization of the information exchanges, in order to create attitudes and behaviours in favour of general interest. So, this decision-making information system could be a socioorganizational support of communication, based on systemics. This theoretical choice permits one to approach the transverse structure and the multidimensional conception of the decision-making information system.
\end{abstract}

Keywords: public awareness strategy, communication, information, risk and uncertainty, decision-making information system.

\section{Introduction}

In the 1970s, at the time of the computerization of areas called Departments in France and before the implementation of public decentralization, within a framework of inter-department cooperation ("Entente Interdépartementale") for fire-fighting, an information system (a database called PROMETHEE) was created. This database concerns the departments of the South of France and it has recorded the main characteristics of forest fires for each year. In the French wildfires prevention and fire-fighting context, this database, founded upon interdepartmental cooperation, is today an Information System (I.S.) at the disposal of the decision makers, in particular for prevention (when, where, how to 
prevent). In reference to the theory of the general system, we define the I.S. as the system that manages the exchanges between the operating system and the system of control. This definition was enriched by the introduction of the systems of knowledge, defined by Ermine [1]. These systems of knowledge represent, indeed, the knowledge held by stockholders of an organization, in relation with the information processing. However, even modified by the introduction of the concepts of inheritance of knowledge, the systemic approach of the I.S. does not allow one to effectively take into account the experience of the main stakeholders implied in wildfires prevention and fire-fighting. That is why we propose a new model of I.S., which could serve to support communication and decision for public awareness about wildfires.

The first part of this paper explains the basis of the project. Our team is involved in the FIRE PARADOX project ( $6^{\text {th }}$ PCRD). We have to set up a public awareness strategy (Badillo and Bourgeois [2]) concerning a new management of fire: the "fire paradox management", which has the goal of being more efficient and more ecological in the fight against wildland fires. FIRE PARADOX is a European integrated project on fire management, coordinated by the Instituto Superior de Agronomia, Universidade Técnica de Lisboa, Portugal (see http://www. fireparadox.org). Concerning public awareness, the objective is to define and propose a communication strategy at the level of the European Union or/and various countries regarding the "fire paradox management". We propose a public awareness strategy relying on an intelligence approach that shows the communication flows among stakeholders and implies the construction of an information system, which synthesizes the complexity of the system. The second part of this paper deals with a model of I.S. that could allow the analysis, the validation and the organization of the information exchanges, in order to create attitudes and behaviours in favour of general interest. We qualify this I.S. as decisional. This decision-making information system (D.M.I.S.) could be a socio-organizational support of communication, based on systemics. This theoretical choice permits one to approach the transverse structure and the multidimensional conception of the decision-making information system.

\section{A strategic intelligence approach: basis of the information system}

Firstly we identify the stakeholders and then we establish the first basis for an information system.

\subsection{Stakeholders: identification of the targets for communication}

Many stakeholders are the targets of information and communication campaigns about wildfires:

a) Property owners within or at the boundary of a forest: some mayors send suitable letters to their residents that are in this situation, in order to remind them of some of their obligations (targets are often selected 
through a geographical information system, as is the case in the city of Venelles, near Aix-en-Provence in the South-East of France).

b) Local residents: they can be reached through the press or through booklets.

c) Farmers and foresters: their associations and the ministries that deal with them are key targets.

d) Motorists: messages on roads and motorways are a good complement in campaigns, especially to avoid throwing burning cigarettes through car windows, especially in case of wind.

e) Tourists and forest hikers: in France, forest hiking is prohibited or regulated when there is a risk of fire; a special information phone number is displayed in the press.

f) Pupils: they are a very important target to motivate their families; comics can be well adapted as a communication support.

g) Other targets such as businesses located at the boundary of a forest.

h) Local elected representatives are another main target.

i) Media: journalists are also, of course, an important target.

\subsection{The maze of today's information stakeholders}

In a systemic approach, we translated into a conceptual model the multiplicity of the target stakeholders and information stakeholders and the various information systems related to prevention and action directed against forest fires. Our analysis shows that there are three main categories of information stakeholders who practice some of the Key Success Factors for a communication campaign:

- Associations of volunteers involved in wildfire prevention.

- Firemen.

- Towns and villages, and associations of towns or villages.

In terms of timing, their actions take place essentially during two periods of the year:

- $\quad$ The season for bush and land clearing.

- The fire season.

Table 1 presents some actions that are related to the different information stakeholders and the seasons.

We have developed a first information system concerning communication on fire in France. We have tried to build an information system on the informationcommunication concerning the prevention of wildfires and the fighting against wildfires; initially at the conceptual level, it is a data model of the MERISE type. We have applied this methodology to the French case. We have distinguished three main levels: the national level, the intermediary level, which in France is mainly the "département" level (at the present stage of our work, we consider that - concerning information flows about fires - the Regional level is the aggregation of the "département" levels), and the local level (municipal level). 
Table 1: $\quad$ Examples of Key Success Factors for a local public sensitization campaign.

\begin{tabular}{|c|c|c|c|c|c|c|}
\hline \multirow{3}{*}{$\begin{array}{l}\text { Associations of } \\
\text { volunteers for } \\
\text { wildfire prevention } \\
\text { (Erample: CCFF } \\
\text { in France) }\end{array}$} & \multicolumn{3}{|c|}{ Period of the year } & \multicolumn{2}{|c|}{ Fire season } & \\
\hline & \multirow[t]{2}{*}{$\begin{array}{l}\text { Presentation } \\
\text { of noe proat: } \\
\text { associatioos }\end{array}$} & $\begin{array}{l}\text { Free astessmeat } \\
\text { for lacdowners }\end{array}$ & $\begin{array}{l}\text { Life of } \\
\text { associations } \\
\text { (vehicle } \\
\text { purchasing,...) }\end{array}$ & $\begin{array}{l}\text { Web site and } \\
\text { phose on } \\
\text { accessibility } \\
\text { of mountain } \\
\text { racges }\end{array}$ & Patrolling & \\
\hline & & $\begin{array}{l}\text { Information } \\
\text { meetings } \\
\text { (difticult) }\end{array}$ & $\begin{array}{l}\text { Senzitization by } \\
\text { neiphbous }\end{array}$ & & & \\
\hline Firemen & & $\begin{array}{l}\text { Explacations } \\
\text { atou: controlled } \\
\text { burning }\end{array}$ & & $\begin{array}{l}\text { Lauching of } \\
\text { a summer } \\
\text { carapugig }\end{array}$ & $\begin{array}{l}\text { Diffusion } \\
\text { of } \\
\text { informat } \\
\text { on fie } \\
\text { respectix } \\
\text { ethical } \\
\text { rules }\end{array}$ & $\begin{array}{l}\text { Assesimeat of } \\
\text { prevention }\end{array}$ \\
\hline \multirow[t]{2}{*}{$\begin{array}{l}\text { Villages and } \\
\text { village associations }\end{array}$} & \multirow[t]{2}{*}{$\begin{array}{l}\text { Call for } \\
\text { tenders (toush } \\
\text { cleuricg) }\end{array}$} & $\begin{array}{l}\text { Local } \\
\text { ecvironvemental } \\
\text { clarter }\end{array}$ & & \multirow{3}{*}{\multicolumn{2}{|c|}{\begin{tabular}{|l} 
Evects : race ugainst tire \\
\end{tabular}}} & \\
\hline & & $\begin{array}{l}\text { Secritization of } \\
\text { local residents or } \\
\text { bush clearivg }\end{array}$ & $\begin{array}{l}\text { Article for } \\
\text { elected members } \\
\text { of local councils }\end{array}$ & & & \\
\hline Miscellaneous & $\begin{array}{l}\text { Reseurch on } \\
\text { risks }\end{array}$ & $\begin{array}{lr}\text { Pecities } & \text { for } \\
\text { failure } & \text { to } \\
\text { complete } & \text { bush } \\
\text { clearng } & \end{array}$ & $\begin{array}{l}\text { Sensitization of } \\
\text { businesses } \\
\text { neighbouring } \\
\text { forests }\end{array}$ & & & $\begin{array}{l}\text { Region of Catalowin } \\
\text { Lafo on expergency }\end{array}$ \\
\hline
\end{tabular}

\subsection{A national information system to describe the main information stakeholders}

This information system gives a very clear comprehension of the complexity of the flows of communication, which are driven by many stakeholders providing many messages to various targets of population with different goals through various media channels. At the national level, different ministries (Agriculture, Internal affairs, Ecology...) are involved in the preventive actions concerning wildfires; and at the "département" level, the Ministers delegate responsibilities to the Prefect, in charge of coordinating actions of prevention with the 
administrative services. The Prefects make sure that the laws are being applied and the Prevention of Risks Plans (PRP) are implemented at the local level of the municipalities. The "département" is managed by the elected members of the "Conseil Général". Each departmental fire service has under its responsibility different local fire stations. Mayors of town halls have the official responsibilities of organising the emergency services. According to the PRP, mayors have to disseminate information on the prevention of wildfires. At the

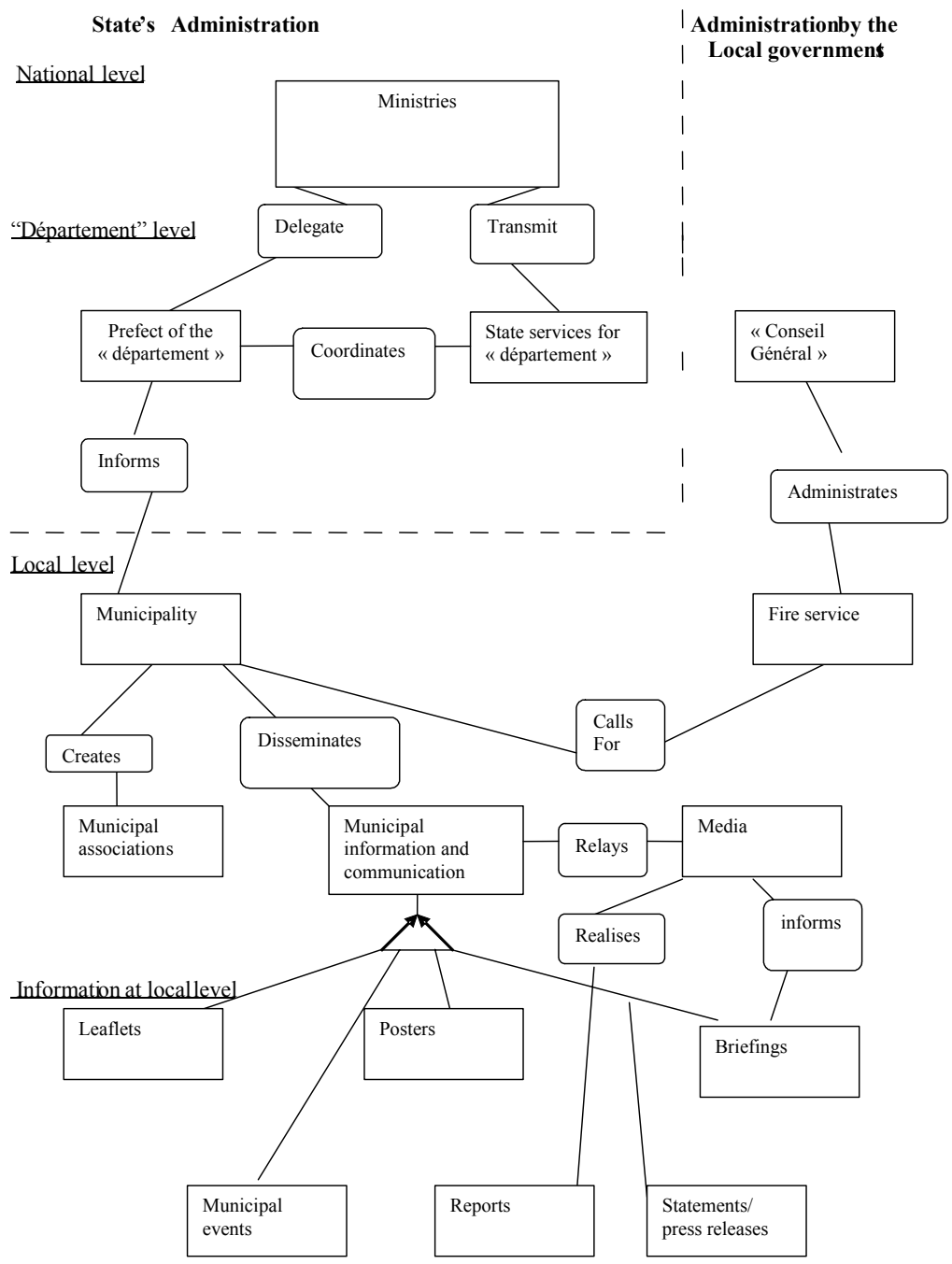

Figure 1: A simplified representation of the French information and communication system concerning fire prevention and fighting against fire (Badillo and Bourgeois [3]). 
local level many actions concerning different targets are developed with different communication tools, such as, for example: leaflets, posters, municipal events, reports, official statements or press releases

\section{The proposed methodological approach: towards a decision-making information system}

In the activities of information watch, the majority of the decisions are mostly unstructured and thus refer to the Simonian model [4]. From this point of view, the contribution of a D.M.I.S. in the decisional practices raises the question of the relations between knowledge, information, action and stakeholders. This organization defines the overall character of the D.M.I.S., which we are going to tackle by a systemic approach (section 3.1), to outline the transverse structure of a D.M.I.S. (section 3.2), in reference to the engineering of knowledge (section 3.3).

\subsection{The theoretical choice of a systemic approach}

Our choice of a systemic approach makes it possible to approach the D.M.I.S. like a system of governorship "stakeholders-machines", itself belonging to the general system "organization", in reference to the theory of the general system (Le Moigne [5]). The general system is structured in three subsystems represented by figure 2 :

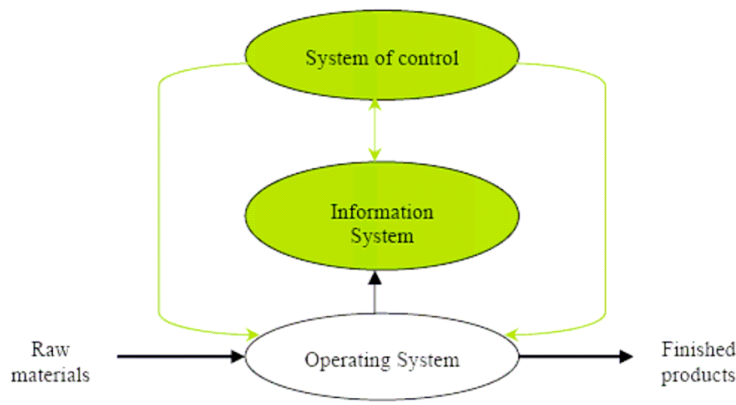

Figure 2: Representation of the general system "organization".

The operating system transforms the raw materials (material and immaterial inputs) into finished products (material and immaterial products). The information system records and memorizes the operations (processes) of the operating system. The system of control coordinates information and the processes by using its cognitive capacities of self-organization. For wildfires, the I.S. corresponds to the database called PROMETHEE, which allows the optimal assignment of the Canadair planes, for example in Corsica. The elements, at the base of the D.M.I.S., are the I.S., the system of control, the relations and the 
interactions between these two systems, to allow "activable" decisions. In reference to Argyris [6], on the "activable" knowledge, we propose to define an "activable" decision as a decision "being at the same time valid and being able to be in motion" ([6], p. 257) at the level of the three systems of the organization. This space of study is represented in grey in figure 2 and is in conformity with the organisational and informational dimensions of decisional activities. Figure 2 is completed by figure 3, which represents the cognitive and temporal dimensions of a decisional practice. This "OIDK Model" (Operation, Information, Decision, Knowledge) is the reference of the systems of knowledge defined by Ermine [1]. It makes it possible to identify and characterize the knowledge and cognitive flows of a system, and in particular of a D.M.I.S. (always specified in grey).

The advantage of such a systemic representation is the global taking into account of four dimensions inherent in the practice of decisions in every organization. The relations and the interactions between the systems give the D.M.I.S. its "communicating" character. However, it is precisely on this point that this systemic representation presents a major disadvantage: the systems (operation, information, decision), hierarchically superposed, generate vertical coordination preventing almost any dynamics of training and devaluating, in the long term, the knowledge system.

\subsection{Outline of a transverse structure}

Under these conditions, and according to our assumption that knowledge is the strategic axis of the design and the development of the D.M.I.S., we make figure 3 swivel by an angle of $90^{\circ}$, which gives figure 4: the social organization of the D.M.I.S. cognitive and informational flows are unchanged. On the other hand, the traditional hierarchical links, resulting from Taylor's model, disappeared to the benefit of transverse links allowing a more open circulation of information and knowledge, generating in its turn a "real" division of knowledge and information.

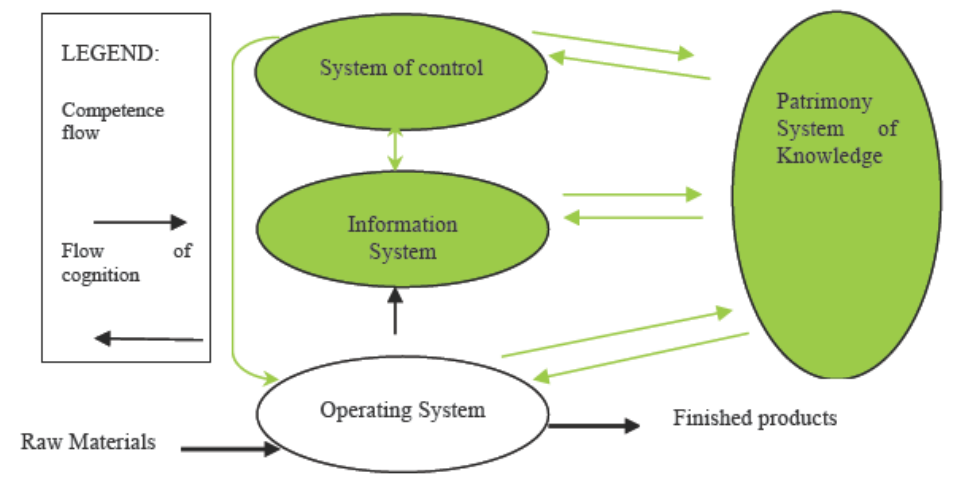

Figure 3: The "OIDK Model" and the space of definition of a D.M.I.S. 


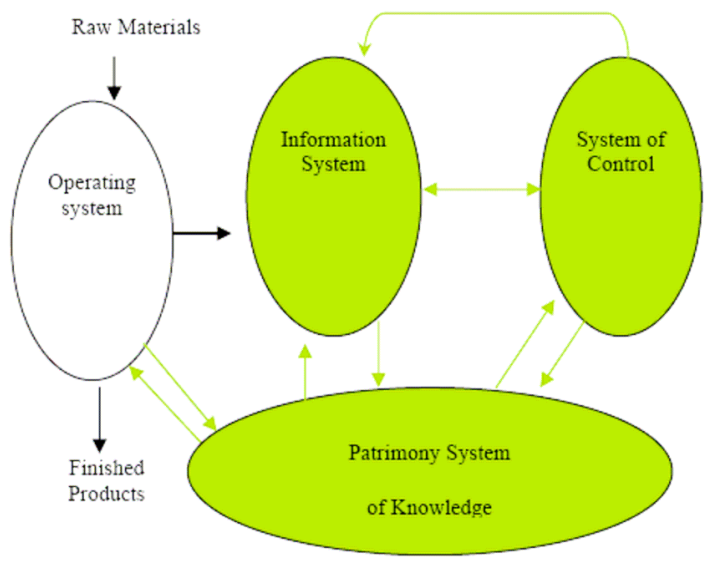

Figure 4: The social organization of the D.M.I.S.

For public awareness about wildfires, the bottom of figure 4 represents the knowledge of stakeholders (such as shepherds and hunters, firemen, foresters...). For the decisional practices, this social organization makes it possible to "plan" the complexity of the decision-making process, before the decision is taken. Hence, the question of the relationship between knowledge and action (decision) arises, as it is one of the major concerns of the engineering of knowledge.

\subsection{The multidimensional conception of the D.M.I.S.}

In our work of investigations on the D.M.I.S., the real situation is the impact of the D.M.I.S. on the "performance" of the decisional actions, organized collectively and individually (in reference to each stakeholder who intervenes in the decision-making process). So the socio-cognitive aspects of training inherent to the decision-making process are taken into account. The decisional activity rests on the triptych: activity, knowledge, organization, proposed by Teulier and Girard ([7], p. 391), in accordance with figure 5.

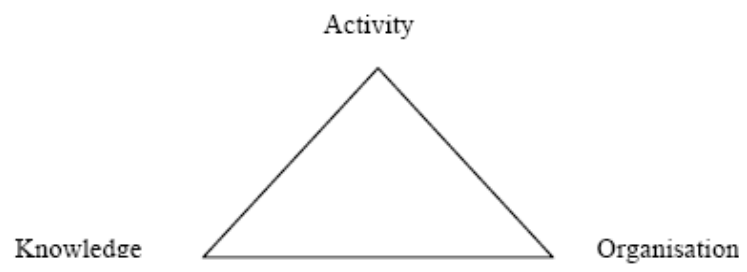

Figure 5: Triangular relations between the concepts of knowledge, activity and organization. 
The advantage of this triptych is to consider the cognitive and organisational dimensions of a decisional practice. The disadvantage is to occult the technological dimension of the D.M.I.S., developed with information and communication technologies (ICT). We propose figure 5, which supplements figure 4. Figure 6 includes the four dimensions specific to the D.M.I.S. This multidimensional conception of the D.M.I.S. is coherent with distributed cognition; this distributed cognition is implemented by artefacts, which help to make an action so that it leads to a successful conclusion. We have chosen to represent these artefacts by the paradigm of the Multi-Agents Systems, with the aim of integrating the collective and individual cognitive activities that intervene in decision-making.

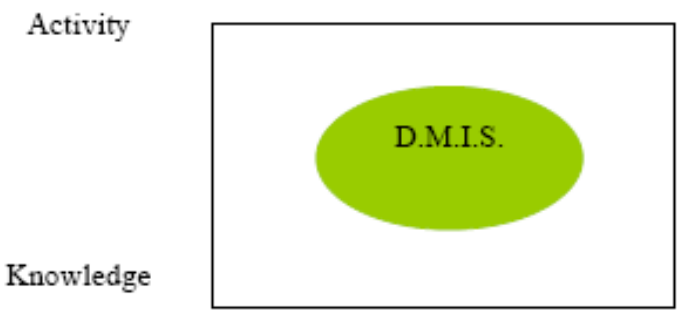

ICT

Organisation

Figure 6: Multidimensional conception of the D.M.I.S.

\section{Conclusion}

We have proposed a new model of I.S. This model integrates the stakeholders' knowledge as a basis of the information/communication process. Taking into account the complexity of the I.S. (see [8]), we have shown the links between the various systems of an organization and the decisional practices. We called this I.S. a D.M.I.S. This type of I.S. could become an inductor of performance, to the detriment of an indicator of performance. For public awareness about wildfires, this I.S. allows one to take into account the various knowledge held by the various stakeholders. The concrete consequence could be better communication on the prevention of wildfires.

\section{References}

[1] Ermine, J.L., Les systèmes de connaissances, Hermès: Paris, 1996.

[2] Badillo, P.-Y. \& Bourgeois, D., Strategic information and communication on forest fires, with some bench marks on natural disasters. Report to the European Commission: synthesis of the state of the art, report to the European Commission in the framework of Module 11, FIRE PARADOX European Integrated Project (project no. FP6-018505, $6^{\text {th }}$ PCRD), April 2008 . 
[3] Badillo, P.-Y. \& Bourgeois, D., Communication, risk and complexity: a new approach applied to the "Fire Paradox" project. IAMCR 2007 International Conference on Media, Information, Communication: Celebrating 50 Years of Theories and Practices, UNESCO, Paris, 23-25 July 2007.

[4] Simon, H.A., Administration et processus de décision, Economica: Paris, 1983.

[5] Le Moigne, J.L., La Théorie du Système Général, PUF: Paris, 1977 \& 1994.

[6] Argyris, C., Savoir pour agir, Interéditions: Paris, 1995.

[7] Teulier, R. \& Girard, N., Modéliser les connaissances pour l'action dans les organisations (Chapter 18), Ingénierie des connaissances, eds R. Teulier, J. Charlet, P. Tchounikine, L’Harmattan: Paris, 2005.

[8] Amabile, S. \& Caron-Fasan, M.-L., Contributions à une Ingénierie des Systèmes d'Information Orientée Complexité (Chapter 3), Faire de la recherche en systèmes d'information, ed. F. Rowe, Vuibert: Paris, pp 67-78, 2002. 